\title{
Cugnaux
}

Lavimona, abords est du Lycée

\section{Gilles Peyre}

\section{(2) OpenEdition}

\section{Journals}

Édition électronique

URL : http://journals.openedition.org/adlfi/10934

ISSN : 2114-0502

Éditeur

Ministère de la culture

\section{Référence électronique}

Gilles Peyre, "Cugnaux », ADLFI. Archéologie de la France - Informations [En ligne], Midi-Pyrénées, mis en ligne le 01 mars 1997, consulté le 20 avril 2019. URL : http://journals.openedition.org/adlfi/10934

Ce document a été généré automatiquement le 20 avril 2019.

(c) Ministère de la Culture et de la Communication, CNRS 


\title{
Cugnaux
}

\author{
Lavimona, abords est du Lycée
}

\section{Gilles Peyre}

Date de l'opération : 1991 (SU)

Inventeur(s) : Peyre Gilles

1 En 1991, une modification des voies d'accès et la réalisation d'un parking aux abords du lycée de Cugnaux ont nécessité la réalisation d'une fouille de sauvetage, sous la direction de Gilles Peyre, dans deux secteurs distants de $400 \mathrm{~m}$.

2 Dans le secteur situé à l'est du lycée, donc au-delà des fossés mis au jour par MarieNoëlle Nacfer ( $c f$. supra), quatre structures de combustion à galets chauffés (une ovoïde, deux circulaires, une allongée et étroite) ont été découvertes.

3 Une fosse de $1,30 \mathrm{~m}$ de diamètre, profonde de $0,80 \mathrm{~m}$, renfermait quatre vases attribuables au Bronze moyen. Une petite fosse de $1 \mathrm{~m}$ de diamètre contenait quelques vestiges $\mathrm{du} 1^{\mathrm{er}}$ s. avant J.-C.

4 Enfin, six fosses de $0,80 \mathrm{~m}$ à 1,60 $\mathrm{m}$ de diamètre ont livré des restes de faune (boeuf, suidé, mouton) associés à des fragments de briques et de céramiques comparables globalement au matériel issu des fosses du site voisin.

\section{INDEX}

Index chronologique : Bronze moyen, Néolithique

Index géographique : Midi-Pyrénées, Haute-Garonne (31), Cugnaux

operation Sauvetage urgent (SU) 